\title{
STIM1 Gene
}

National Cancer Institute

\section{Source}

National Cancer Institute. STIM1 Gene. NCI Thesaurus. Code C20862.

This gene plays a role in hematopoiesis and may play a role in malignant development. 